Brit. F. vener. Dis. (1969), 45, 121.

\title{
IMMUNOGLOBULINS OF CEREBROSPINAL FLUID IN SYPHILIS*
}

\author{
BY \\ VIVI-ANNE OXELIUS, H. RORSMAN, AND ANNA-BRITA LAURELL \\ Department of Medical Microbiology and Department of Dermatology, University of Lund, Lund, Sweden
}

During an immunization process IgM antibodies generally appear earlier than IgG antibodies. At a later stage IgG antibodies are the predominant antibody type. Some antigens, however, stimulate predominantly IgM antibodies for long periods, even years (Uhr, 1964). In syphilis Wassermann antibodies may be found in IgG or in IgM or in both (Laurell and Malmquist, 1961).

In a study of serum immunoglobulin levels, high concentrations of serum IgM have been demonstrated in cases of late untreated syphilis and it has been found that this increase may be selective (Laurell and Rorsman, 1966; Laurell, Oxelius, and Rorsman, 1968). It has been suggested that high levels of IgM in sera from patients with a history of syphilis might be a sign of activity of the disease.

In the present study the immunoglobulin levels of cerebrospinal fluid were determined by an immunological technique. It was found that these determinations might be helpful in deciding whether late syphilis is active or not.

\section{Material and Methods}

Cerebrospinal fluid (CSF) was obtained by lumbar puncture from seven patients with syphilis; one of them had secondary syphilis and six had neurosyphilis. CSF was also obtained from ten patients who had earlier been treated for neurosyphilis. In all cases the serum TPI test was positive. In the case of secondary syphilis and in three of the six cases of neurosyphilis samples were obtained both before and after penicillin treatment; the CSF specimens were kept at $-20^{\circ} \mathrm{C}$. until studied.

Total Protein Concentration of CSF This was determined according to the Folin-Ciocalteu method (Lowry, Rosebrough, Farr, and Randall, 1951). Normal range $25-80 \mathrm{mg}$. $/ 100 \mathrm{ml}$.

$\operatorname{IgG}, \operatorname{Ig} A$, and $\operatorname{Ig} M$ in CSF These were measured

$\star$ Received for publication October 17, 1968. by Oudin's single diffusion tube technique (Oudin, 1952). Specific, absorbed rabbit antisera against human serum IgG, IgA, and IgM, respectively, in proper dilutions, were mixed with Reinagar $1 / 3$ per cent. and added to tubes with an internal diameter of $2 \mathrm{~mm}$. CSF to be examined was diluted $1 / 2$ in 5 per cent. human albumin solution and poured on to the antiserum-agar column. Diffusion was allowed to proceed for 23, 24, and 25 hours respectively at room temperature $\left(22^{\circ} \mathrm{C}\right.$. $)$. A reference curve was obtained with dilutions of a pool of normal sera by measuring the distance that the precipitate had migrated. Purified 5 per cent. human albumin solution was used as diluent for the normal serum pool. The correlation between the logarithm of the concentration and the migration distance of the precipitate was largely linear. The error calculated from double readings of the migration distance was \pm 0.03 mm., i.e. \pm 5 per cent. The results were given as the mean of double estimations. The lowest concentrations measurable with this technique were: for IgG, 0.005; for IgA, 0.05; and for IgM, 0.8 per cent. of the normal serum pool. In CSF obtained from ten adults with disc prolapse, the IgG concentration was $0.05-0.16$ per cent. of a normal serum pool. IgA and IgM were not present in measurable amounts in the CSF of these patients.

$\alpha_{2}$-Macroglobulin of CSF This was measured by Oudin's single diffusion tube technique as described above, using a specific rabbit antiserum against human $\alpha_{2}$-macroglobulin prepared as described by Ganrot (1966). $\alpha_{2}$-Macroglobulin was not present in measurable amounts in the samples obtained from ten patients with disc prolapse.

Wassermann and Meinicke Reactions These were performed according to the routine technique of this institute.

Antigen-antibody Crossed Electrophoresis This was performed according to the method of Laurell (1965). 


\section{Results}

Secondary Syphilis One patient with untreated secondary syphilis was studied (Table I) The total protein of the CSF was increased to $150 \mathrm{mg}$. $/ 100 \mathrm{ml}$. The IgG, IgA, and $\alpha_{2}$-macroglobulin of the CSF were elevated. No IgM could be shown in the CSF with the technique used. The Wassermann and Meinicke reactions of CSF were positive. In CSF obtained 8 months after treatment with penicillin, the total protein and IgG were within normal ranges and the IgA, IgM, and $\alpha_{2}$-macroglobulin were below detectable levels. The Wassermann and Meinicke reactions had become negative.

Neurosyphilis In the cases of untreated neurosyphilis the total protein concentration was increased. Markedly increased amounts of the immunoglobulins of the CSF were found (Table II).

In five of these cases IgM was increased, in four of them up to values of 8 to 10 per cent. of the normal serum pool concentration. The IgG and IgA were also increased, the increase of IgG being much more pronounced than that of IgA. $\alpha_{2}-$
Macroglobulin was present in detectable amounts in four of five cases investigated in this respect.

Samples of CSF from three of the patients with neurosyphilis were collected before and after treatment with penicillin (Table III). After penicillin treatment, IgM fell rapidly below the measurable level, while the IgG and IgA levels fell slowly. Investigation of CSF from thirteen patients who had been treated for neurosyphilis showed that a few months after treatment the IgM levels were below detectable level ( $<0.8$ per cent.). $\alpha_{2}$-Macroglobulins were not measurable in any of these cases. The IgG and IgA levels at different intervals after treatment are given in Fig. 1. The IgG and IgA were increased for as long as 13 years after treatment.

Sera from three of the six patients with untreated neurosyphilis were found to contain normal or slightly increased amounts of IgG and IgA. IgM was increased in all three cases, in one up to 350 per cent.

CSF and serum from one of the patients were investigated by antigen-antibody crossed electrophoresis. The anodal peak of the CSF IgG was situated more cathodically than that of the serum IgG (Fig. 2).

TABLE I

IMMUNOGLOBULINS OF CSF BEFORE AND AFTER TREATMENT IN A FEMALE CASE OF SECONDARY SYPHILIS

\begin{tabular}{|c|c|c|c|c|c|c|c|}
\hline \multirow{2}{*}{ Date } & \multicolumn{4}{|c|}{ Per cent. of a Normal Serum Pool } & \multirow{2}{*}{$\begin{array}{c}\text { Total } \\
\text { Protein } \\
\text { (mg. } / 100 \mathrm{ml} .)\end{array}$} & \multirow{2}{*}{$\begin{array}{l}\text { Wasserman } \\
\text { Titre }\end{array}$} & \multirow{2}{*}{$\begin{array}{c}\text { Cells/mm. } \\
\text { (Poly/Mono) }\end{array}$} \\
\hline & IgG & IgA & $\operatorname{IgM}$ & $\alpha_{2} M$ & & & \\
\hline September 12,1966 & $1 \cdot 3$ & 0.5 & $<0.8$ & $0 \cdot 2$ & 150 & $1 / 8$ & $0 / 10$ \\
\hline October $19,1966^{\star}$ & 0.3 & $<0.05$ & $<0.8$ & $<0.05$ & 75 & - & $0 / 2$ \\
\hline March 1, 1967 & 0.1 & $<0.05$ & $<0.8$ & $<0.05$ & N.D. & - & N.D. \\
\hline May 21, 1968 & 0.1 & $<0.05$ & $<0.8$ & $<0.05$ & 47 & - & $0 / 4$ \\
\hline
\end{tabular}

^Penicillin treatment September 14 to September 30, 1966. N.D. $=$ Not done.

TABLE II

IMMUNOGLOBULINS OF CSF IN CASES OF NEUROSYPHILIS BEFORE TREATMENT

\begin{tabular}{|c|c|c|c|c|c|c|c|c|c|c|}
\hline \multirow{2}{*}{$\begin{array}{l}\text { Patient } \\
\text { No. }\end{array}$} & \multirow{2}{*}{ Sex } & \multirow{2}{*}{$\begin{array}{l}\text { Age } \\
\text { (yrs) }\end{array}$} & \multicolumn{4}{|c|}{ Per cent. of a Normal Serum Pool } & \multirow{2}{*}{$\begin{array}{c}\text { Total } \\
\text { Protein } \\
(\mathrm{mg} . / 100 \mathrm{ml} .)\end{array}$} & \multirow{2}{*}{$\begin{array}{c}\text { Wassermann } \\
\text { Titre }\end{array}$} & \multirow{2}{*}{$\begin{array}{c}\text { Cells/mm. } \\
\text { (Poly/Mono) }\end{array}$} & \multirow{2}{*}{ Clinical Type } \\
\hline & & & IgG & $\operatorname{Ig} A$ & IgM & $\alpha_{2} M$ & & & & \\
\hline 1 & $\mathbf{M}$ & 37 & $3 \cdot 0$ & $0 \cdot 2$ & $8 \cdot 0$ & $\sim 0.05$ & 140 & $1 / 64$ & $0 / 30$ & General paresis \\
\hline 2 & $\mathbf{M}$ & 71 & $3 \cdot 1$ & $0 \cdot 4$ & $8 \cdot 0$ & $0 \cdot 2$ & 225 & $1 / 32$ & $0 / 23$ & Meningovascular \\
\hline 3 & $\mathbf{M}$ & 53 & $2 \cdot 8$ & N.D. & $8 \cdot 4$ & N.D. & N.D. & $1 / 32$ & $16 / 84$ & $\begin{array}{l}\text { Bilateral optic } \\
\text { atrophy }\end{array}$ \\
\hline 4 & $\mathbf{M}$ & 73 & $3 \cdot 0$ & $0 \cdot 6$ & $10 \cdot 0$ & $0 \cdot 2$ & 170 & $1 / 32$ & $1 / 10$ & General paresis \\
\hline 5 & $\mathbf{F}$ & 45 & $1 \cdot 4$ & $\sim 0.05$ & $<0.8$ & $\sim 0.05$ & 95 & $1 / 8$ & $8 / 14$ & Asymptomatic \\
\hline 6 & $\mathbf{F}$ & 63 & $1 \cdot 6$ & 0.4 & $2 \cdot 3$ & $<0.05$ & 119 & $1 / 16$ & $30 / 132$ & Asymptomatic \\
\hline
\end{tabular}


TABLE III

IMMUNOGLOBULIN VALUES OF CSF BEFORE AND AFTER PENICILLIN TREATMENT IN THREE CASES OF NEUROSYPHILIS

\begin{tabular}{|c|c|c|c|c|c|c|c|c|c|c|}
\hline \multirow{2}{*}{$\begin{array}{c}\text { Patient } \\
\text { No. }\end{array}$} & \multirow{2}{*}{ Sex } & \multirow{2}{*}{$\begin{array}{c}\text { Age } \\
\text { (yrs) }\end{array}$} & \multirow{2}{*}{ Date } & \multicolumn{4}{|c|}{ Per cent. of a Normal Serum Pool } & \multirow{2}{*}{$\begin{array}{c}\text { Total } \\
\text { Protein } \\
(\mathrm{mg} \cdot / 100 \mathrm{ml} .)\end{array}$} & \multirow{2}{*}{$\begin{array}{l}\text { Wassermann } \\
\text { Titre }\end{array}$} & \multirow{2}{*}{$\begin{array}{c}\text { Cells/mm. } \\
\text { (Poly/Mono) }\end{array}$} \\
\hline & & & & IgG & IgA & $\operatorname{Ig} M$ & $\alpha_{2} M$ & & & \\
\hline \multirow[t]{3}{*}{2} & \multirow[t]{3}{*}{$\mathbf{M}$} & \multirow[t]{3}{*}{71} & April 16, 1966 & $3 \cdot 1$ & 0.4 & $8 \cdot 0$ & $0 \cdot 2$ & 225 & $1 / 32$ & $0 / 23$ \\
\hline & & & September $12,1966^{\star}$ & $3 \cdot 6$ & $0 \cdot 2$ & $<0.8$ & $\sim 0.05$ & 160 & $1 / 32$ & $0 / 8$ \\
\hline & & & March 17, 1967 & $1 \cdot 6$ & $0 \cdot 3$ & $<0.8$ & $<0.05$ & 165 & $1 / 16$ & $2 / 5$ \\
\hline \multirow[t]{2}{*}{5} & \multirow[t]{2}{*}{$\mathbf{F}$} & \multirow[t]{2}{*}{45} & February 15, 1967 & $1 \cdot 4$ & $\sim 0.05$ & $<0.8$ & $<0.05$ & 95 & $1 / 8$ & $8 / 14$ \\
\hline & & & April $1,1968^{\star \star}$ & $0 \cdot 4$ & $<0.05$ & $<0.8$ & $<0.05$ & 53 & $1 / 8$ & $0 / 3$ \\
\hline \multirow[t]{2}{*}{6} & \multirow[t]{2}{*}{$\mathrm{F}$} & \multirow[t]{2}{*}{63} & March 29, 1968 & $1 \cdot 6$ & 0.4 & $2 \cdot 3$ & $<0.05$ & 119 & $1 / 16$ & $0 / 32$ \\
\hline & & & May $6,1968^{\star \star \star}$ & $1 \cdot 0$ & $0 \cdot 2$ & $<0.8$ & $<0.05$ & 145 & $1 / 16$ & $0 / 31$ \\
\hline
\end{tabular}

$\star$ Penicillin treatment April 16 to May 2, 1966.

$\star \star$ Penicillin treatment February 15 to March 4, 1967.

$\star \star \star$ Penicillin treatment April 17 to May 3, 1968 .

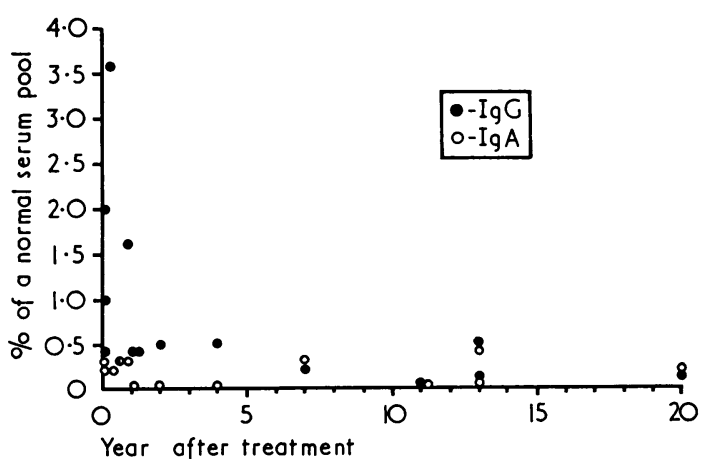

FIG. 1.-IgG and IgA values of CSF of thirteen patients with neurosyphilis at different intervals after treatment with penicillin.

\section{Discussion}

Analysis of the proteins of CSF has long been used in the investigation of patients with syphilis. Studies before 1955 have been extensively reviewed by Flodén (1955), who compared paper electrophoresis with earlier methods.

An increase of the $\gamma$-globulin fraction of CSF in neurosyphilis is well known (Kabat, Landow, and Moore, 1942; Kabat, Moore, and Landow, 1942; Schultze and Heremans, 1966). Frick and ScheidSeydel (1958) found some evidence that the increase of $\gamma$-globulin in CSF is due to a local production within the central nervous system.

There is a relationship between the molecular weight and the concentrations of various plasma proteins in CSF. The CSF/serum concentration ratio of albumin is 0.004 (Schultze and Heremans, 1966) and that of IgG is about 0.001. Rosenthal and Soothill (1962) calculated the CSF/serum 
molecular sieve concept of the blood-CSF protein transport.

With the technique used in the present investigation, IgM and $\alpha_{2}$-macroglobulin were not detectable in normal CSF. While a parallel increase of IgM and $\alpha_{2}$-macroglobulin is a sign of a damage of the blood-brain barrier, an increase in IgM without a concomitant increase in $\alpha_{2}$-macroglobulin may indicate a local production of IgM within the central nervous system. IgG and IgA, which are molecules of roughly equal size, are found in normal CSF in about the same ratio as in serum. A change in this ratio in CSF might indicate a local production of either of these two proteins within the central nervous system.

In the case of secondary syphilis, the IgG and IgA of the CSF were increased and the $\alpha_{2}$-macroglobulin was elevated. With the technique used no IgM could be demonstrated. These findings indicate damage to the blood-brain barrier in this stage of the disease. The finding of a higher relative value of IgG than of IgA might, however, indicate a local production of IgG. Nørredam and Clausen (1963), who reported immunoelectrophoretic studies of CSF proteins in early syphilis, found evidence for a local production of $\gamma$-globulins. In some of their cases $\alpha_{2}$-macroglobulin was increased.

The findings in our six cases of untreated neurosyphilis indicated a disorder of the blood-brain barrier. The increase in $\alpha_{2}$-macroglobulin was moderate compared with the markedly high concentration of IgM in the CSF, which favours the idea of a local production of IgM. The more pronounced increase in IgG than in IgA in these patients, may also be explained by a local production of IgG.

A passive transfer of serum IgG to the CSF would be expected to give identical electrophoretic patterns of CSF and serum. However, the more cathodal position of the peak of CSF IgG compared with that of serum demonstrated by the antigenantibody electrophoresis in one of these cases of untreated neurosyphilis may support the possibility of local production of IgG (Esser, 1952).

The method used for determination of IgM does not permit detection of concentrations below 0.8 per cent. of that of a normal serum pool. In the case of five of the six patients who had not received antisyphilitic treatment, IgM of the CSF was markedly increased. By contrast, no patient with treated syphilis had CSF IgM in detectable concentrations. The IgM level fell rapidly after treatment with penicillin. It is possible that persistence of IgM in CSF requires the presence of living spirochaetes. Persistence of IgM in CSF of these patients might be a means of judging the activity of the infection.

The increase of CSF IgG, in cases of treated neurosyphilis persisted for a long time after treatment. This finding may be in accordance with the observation made in kinetic studies of various IgG antibody systems, namely that after an intense antigenic stimulus the clone producing IgG antibodies persists for a long time (Uhr, 1964).

\section{Summary}

Levels of immunoglobulins in the CSF were determined with Oudin's single diffusion technique in cases of cerebrospinal syphilis. The findings in untreated neurosyphilis and in one case of secondary syphilis indicated damage to the blood-brain barrier. In untreated neurosyphilis the results also provided evidence suggesting local production of IgG and IgM. After treatment of patients with neurosyphilis, the IgG levels of CSF decreased slowly, while IgM fell rapidly. Determination of the levels of the immunoglobulins and $\alpha_{2}$-macroglobulin of CSF may be helpful in assessing the activity of a neurosyphilitic infection.

This work was supported by grants from Alfred Österlunds Stiftelse.

\section{REFERENCES}

ESSER, V. (1952). Munch. med. Wschr., 94, 2313.

Flodén, C.-H. (1955). Acta derm.-venereol. (Stockh.), 35, Suppl. 32.

FrICK, E., and ScheId-SEYdeL, L. (1958). Klin. Wschr., 36, 66, 857.

GaNRot, P. O. (1966). Clin. chim. Acta, 14, 493.

Kabat, E. A., Landow, H., and MoORE, D. H. (1942).

Proc. Soc. exp. Biol. (N.Y.), 49, 260.

-, MOORE, D. H., and LANDOw, H. (1942). f. clin. Invest., 21, 571.

LaURell, C.-B. (1965). Analyt. Biochem., 10, 358.

and Malmeurst, J. (1961). Acta path. microbiol. scand., 51, 187.

- Oxelius, V.-A., and Rorsman, H. (1968). Acta derm.-venereol. (Stockh.), 48, 268.

- and RoRsman, H. (1966). Ibid., 46, 406.

LOWRY, O. H., ROSEBrough, N. J., FARR, A. L., and RANDALl, R. J. (1951). f. biol. Chem., 193, 265.

Nørredam, K., and Clausen, J. (1963). Acta derm.venereol. (Stockh.), 43, 413.

Oudin, J. (1952). Meth. med. Res., 5, 335.

Rosenthal, F. D., and Soothill, F. J. (1962). F. Neurol. Nerosurg. Psychiat., 25, 177.

SChUltZE, H. E., and Heremans, J. F. (1966). "Molecular Biology of Human Proteins", vol. 1, p. 732. Elsevier, Amsterdam.

UHR, J. W. (1964). Science, 145, 457. 
Les immunoglobulines du liquide céphalo-rachidien dans la syphilis

\section{RÉSUMÉ}

Les taux d'immunoglobulines du L.C.R. ont été déterminés par la technique de simple diffusion d'Oudin dans des cas de syphilis cérébro-spinale. Les observations dans les cas non-traités de neuro-syphilis et dans un cas de syphilis secondaire ont indiqué des dommages à la barrière entre le sang et le cerveau. Dans la neurosyphilis non-traitée les résultats ont aussi donné des preuves suggérant la production locale d'IgG et d'IgM. Après le traitement des malades atteints de neurosyphilis, les taux d'IgG du L.C.R. ont diminué lentement, tandis que ceux d'IgM ont baissé rapidement. La détermination des taux des immunoglobulines et de $l^{\prime} \alpha_{2}$-macroglobuline du L.C.R.peut être utile pour évaluer l'activité d'une infection neuro-syphilitique. 